\title{
Treatment of Resistant Clubfoot with Soft Tissue Release and Alkhooly External Fixator*
}

\author{
Ali Zein A. A. Al-Khooly", Mohamed Ali Ahmed Mohamed, Ebrahim El-Hawary Ali \\ Department of Orthopedic and Trauma, El-Minia University Hospital, El-Minia, Egypt. \\ Email: "profalizein@yahoo.com
}

Received September $10^{\text {th }}, 2013$; revised October $15^{\text {th }}, 2013$; accepted October $29^{\text {th }}, 2013$

Copyright (C) 2013 Ali Zein A. A. Al-Khooly et al. This is an open access article distributed under the Creative Commons Attribution License, which permits unrestricted use, distribution, and reproduction in any medium, provided the original work is properly cited.

\begin{abstract}
After the first research with this technique done by the first author, ten operations on the foot and ankle were performed on five patients (two boys and three girls) suffering from severe club foot deformity all with bilateral foot affection. Their ages ranged from five to fourteen years. All of them were treated by soft tissue release, skin flap (rotational flap), supplemented with Alkhooly external fixator. The follow up period ranged from two to seven years. The results according to Mittal (1987) [1] were excellent in eight feet (80\%) and good in two feet (20\%).
\end{abstract}

Keywords: Clubfoot-External Fixator; Soft Tissue Release

\section{Introduction}

The treatment of clubfoot is controversial, because its cause remains unknown, its pathological anatomy is uncertain and its behavior is unpredictable [2].

Some authors concluded that there are different etiological factors responsible for resistance to correction or recurrence after correction [3-8].

A high incidence of recurrence ranging from $36 \%$ to $68 \%$ with conservative and operative treatment has been reported by many authors [8-10]. Recently there has been a trend towards very early soft-tissue release procedures on the basis that this congenital abnormality is best treated early in order to prevent affection of uncorrected deformity on normal bone growth [11-14].

The uneven wound closure and the difficulty with skin coverage that may follow the operative correction of severe congenital and acquired deformities of the foot and ankle are well-recognized problems. These complications may result in wound infection, skin sloughing, fibrosis, recurrence of the deformity and a generalized increase in morbidity [15]. Moreover, the long medial curvilinear

\footnotetext{
*NB. The first research with this technique was done by prof. Ali Zein A.A. Alkhooly and published in German Journal of Foot and Ankle Surgery, August 2003, A.Z.A.A.Al-Khooly (2003): eight year's experience with soft tissue release and Alkhooly external fixator in the treatment of resistant clubfoot, German Journal of Foot and Ankle Surgery. Band 1. Heft 3. August 2003-(199-207).

${ }^{\#}$ Corresponding author.
}

incision that extends across joints is subjected either to hypertrophic scarring or keloid formation or both. The scarring and fibrosis lead to skin contracture on postero-medial aspect which is a potent deforming element and an important factor in recurrence. Therefore, it must be avoided to reduce the danger of medial tethering from secondary scarring.

The early postoperative management and the required degree of correction of the deformity can not be achieved completely by plaster cast alone. Therefore, the use of an external fixator was found more reliable.

The principles of external fixation for treatment of late deformed club foot are well established and there are many papers which testify to the use of an Ilizarov frame in management. Certainly the frame described by $\mathrm{Mr}$. ALKHOOLY is novel and simple (Michael K.D. Benson, December 1995, personal letter).

In this research the authors follow the same technique of the first author in the first research and the results were encouraging so the aim of this work is to conclude the validity of this technique in the treatment of resistant and severe neglected cases of club foot.

\section{Material and Methods}

The studied series includes ten feet in five patients, two boys and three girls, their ranged from five to fourteen, all have severe bilateral deformity, eight of them were 
treated from birth by repeated manipulation and repeated plaster cast but not corrected, and two of them were neglected.

Follow up period from two to seven years.

\subsection{Preoperative Assessment}

Clinically: All children were examined clinically before operation, and the degree of various components of deformity and the condition of the skin and muscles were recorded. All cases were idiopathic congenital clubfeet.

Radiologically: A-P and lateral X-rays were made for assessment of the degree of deformity.

\subsection{Operative Procedure}

\subsubsection{Skin Incision}

The incision had two parts: the foot and the leg part (Figure 1).

The foot part: Semi-circular incision extending from the base of the 5th metatarsal at the dorso-lateral aspect of the foot to the dorso-medial aspect, extending to the plantar aspect and then straight back to the insertion of tendo-Achillis.

The leg part: Longitudinal incision extending proximally from the insertion of tendo-Achillis to the lower third of the leg. Then a thick skin flap is raised for about $2 \mathrm{~cm}$.

\subsubsection{Soft Tissue Release}

Medial, Posterior and Subtalar Release. All tight structures on the medial and poster medial side were released posterior capsulotomy of the ankle, tenotomy of abductor hallucis (at its insertion in the big toe) and release of the plantar fascia.

\subsubsection{Alkhooly External Fixator (Figure 2)}

A K. wire $2 \mathrm{~mm}$ in diameter was introduced transversely through the distal part of all metatarsal shafts. Another K. wire was passed transversely through the calcaneus parallel to the first one.

The ends of both $\mathrm{K}$. wires were placed in the holes of the fixator according to the degree of correction of the deformity. The first K. wire was passed in the distal half ring, the second $\mathrm{K}$. wire in the proximal half-ring and the joint of the fixator was adapted according to correction of the deformity.

The upright bars of the fixator were included in the above-knee plaster cast. With the knee joint in $90^{\circ}$ of flexion, the foot and leg were in slight external rotation to correct internal tibial torsion.

\subsubsection{Skin Closure}

The skin was closed by rotation of the flap medially and posteriorly (Figure 1).

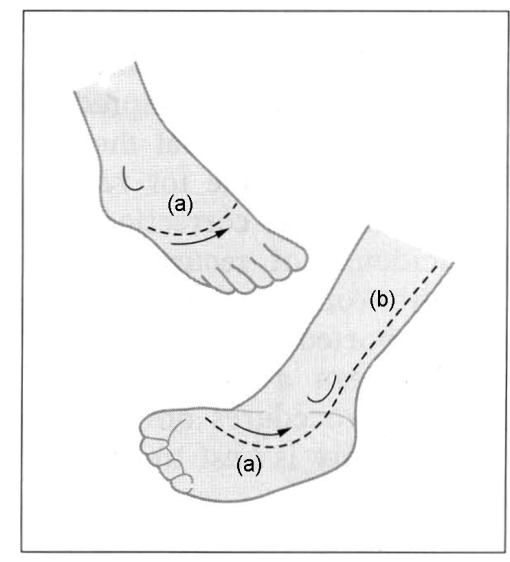

Figure 1. Diagram showing the skin flap. Foot part (a) and leg part (b). The arrow showing the direction of rotation of the flap.

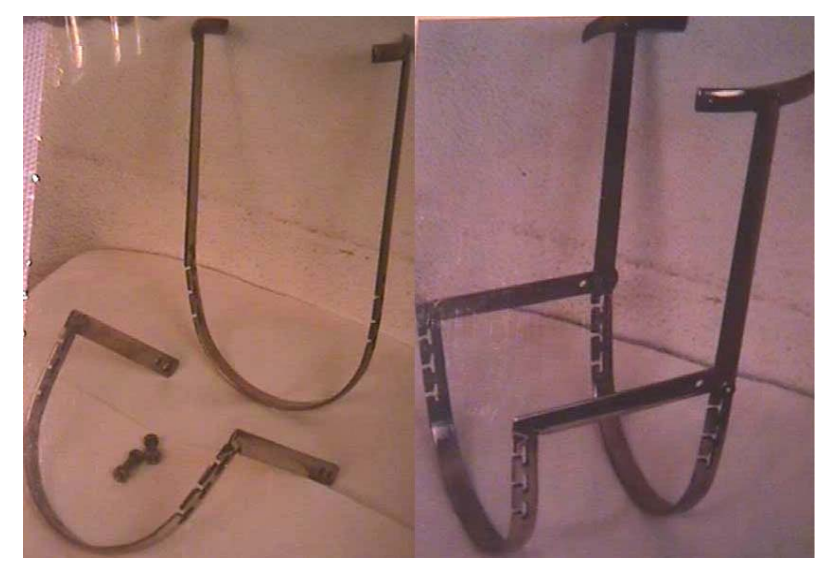

Figure 2. Alkhooly external fixator. This Fixator was introduced by Prof. Ali Zein Alabedeen A. Alkhooly and approved in 29/4/1997 under No. 20089.

\subsubsection{Post-Operative Care}

Post-operative care included the following: observation of the circulation, correction of the deformity when needed, (by changing the position of $\mathrm{K}$. from one hole to the next hole, position of side bar or joint of the fixator) and avoidance of any circulatory embarrassment and early movement of the toes.

\subsubsection{Time of Removal of the Fixator}

After 4 to 6 weeks and complete healing of wounds, the $\mathrm{K}$. wires and fixator were removed followed by application of an above-knee plaster cast in a well-corrected position (with the knee at 90 degree of flexion, the leg portion of the cast, which includes the foot, was held in slight external rotation) for anther 6 weeks.

\subsubsection{Treatment Duration}

Overall treatment time ranged from 10 to 12 weeks. After removal of the cast, short period of physiotherapy then the child was allowed to walk. 


\subsection{Post-Operative Assessment}

\subsubsection{Clinically}

Patients were examined clinically for wound healing degree of correction of deformity and foot stiffness.

\subsubsection{Radiologically}

A-P X-rays were made with the foot in 30 plantar-flexion and the tube directed caudally 30 from perpendicular [10]. Lateral X-rays were taken with the foot in 30 plantar flexion and another with the foot in the neutral position.

\subsubsection{Functionally}

The evaluation of function included whether the child had any pain, can walk normally, can walk on uneven ground, can run normally and can wear normal shoes (parents of the children gave us most of the above data).

\section{Results}

\subsection{Clinically}

The results are classified clinically according to Mittal [1] as excellent, good, and poor (Criteria of assessment; clinical results Tables 1(a) and (b)).

Excellent has the following criteria: healthy scar, the deformity fully corrected, the foot in fully plantgrade without any hidden equinus (the heel does not touch the ground while sitting on the feet).

Good has the following criteria: healthy scar, the foot is fully plantgrade without any equines or minor degree of deformity.

Poor has the following criteria: moderate deformity, contracture of the scar and valgus foot deformity (due to over correction).

Eight from ten had excellent results (80\%). Two feet had good results (20\%) with mild residual adduction because the side bar of the fixator was not fixed in the correct position early which is corrected by repeated ma-

Table 1. (a) Criteria of assessment; (b) Clinical results.

\begin{tabular}{|c|c|c|}
\hline Excellent & \multicolumn{2}{|c|}{$\begin{array}{l}\text { Healthy scar, the deformity fully corrected, the foot } \\
\text { in fully plantgrade without any hidden equinus (the } \\
\text { heel does not touch the ground while sitting on the } \\
\text { feet). }\end{array}$} \\
\hline Good & \multicolumn{2}{|c|}{$\begin{array}{l}\text { Healthy scar, the foot is fully plantgrade without } \\
\text { any equines or minor degree of deformity. }\end{array}$} \\
\hline Poor & \multicolumn{2}{|c|}{$\begin{array}{l}\text { Moderate deformity, contracture of the scar and } \\
\text { valgus foot deformity (due to over correction). }\end{array}$} \\
\hline \multicolumn{3}{|c|}{ (b) } \\
\hline Degree & No. of feet & Percent \\
\hline Excellent & 8 & $80 \%$ \\
\hline Good & 2 & $20 \%$ \\
\hline Total & 10 & $100 \%$ \\
\hline
\end{tabular}

nipulation and cast. Mild superficial infection occurred in three cases, which healed rapidly without any other complications. After removal of the plaster cast, all feet had a mild degree of stiffness. However, the normal range of movement was regained rapidly after a short period of rehabilitation. No bony operation had been done.

\subsection{Radiologically (After Removal of the Cast)}

\subsubsection{Cavus Deformity (Figure 3)}

Measured on lateral X-ray: the angle between the axis of the first metatarsal and the axis of the calcaneus, which is named plantaris angle or forefoot Equinus [16]. In our cases this angle improved in serial follow up X-ray.

\subsubsection{Varus Deformity of the Heel}

The angle between long axis of talus and calcaneus in A-P X-rays [18]. In our cases, this angle improved in serial follow up X-ray.

\subsubsection{Adduction of the Fore Part of the Foot}

The angle between axis of calcaneus and fifth metatarsal bone in A-P X-rays [16]. In our cases, this angle improved in serial follow up X-ray.

\subsubsection{Equinus Deformity of the Ankle (Figure 4)}

This was measured by the angle formed by the axis of the shaft of the tibia and long axis of the calcaneus on lateral X-ray [19] this angle improved in serial follow up X-ray.

Radiological follow up: marked improvement in follow up X-ray (Figures 5(a) and (b)).

\subsection{Functional Assessment}

- All feet had good flexibility no pain or discomfort and the gait was good after a short period of rehabilitation.

Case study (Figures 6(a) and (b)) case of bil. Congenital talipes equino-varus

The same case after operation in the fixator (Figure 7).

The same case post-operative (Figures 8 and $\mathbf{9}$ ).

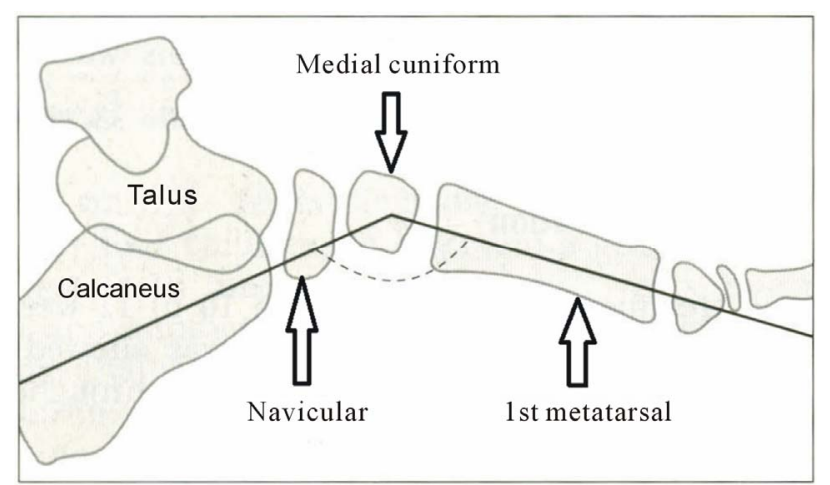

Figure 3. Plantaris angle. 


\section{Discussion}

Although the treatment of a mild congenital clubfoot may be easy, the complete and permanent correction of severe and rigid clubfoot is often difficult [16]. Most authors still agree that all congenital clubfeet should initially be treated non-operatively [20,21].

Bensahel et al. [22] recommended in 1987 that the initial treatment should consist of daily manipulation of the foot without anesthesia for three months. This was followed by adhesive strapping of the foot in the corrected position. If the deformity did not respond to this regime after three months surgical interference was advised.

Several techniques for surgical treatment of club-foot were described in the literature [17]. Their indications varied with the age of the patient and the degree of deformity. Some authors reported good results with soft-tissue release, even at the age of 8 - 10 years [23]. Other authors reported an opposite view [24,25].

Turco introduced in 1978 [26] the one stage soft tissue posteromedial release. This is still used widely today $[27,28]$ He advised that the optimum age of candidates for this procedure was one to two years, with an upper limit of six years.

The contracture of the posteromedial skin is an impediment to correction in severe deformities at all ages. Hence, its release is always indicated [1]. The use of a rotation skin flap will solve the problem. Mittal [1] described the dorsolateral semicircular flap rotated posteromedially, thus allowing the lax skin on the dorsolateral aspect to shift planterwards and backwards. The other problem is the final correction with prevention of neurovascular complications and good observation of the foot; this is not achieved completely by repeated changing of the plaster cast with the possibility of loss of correction and recurrence of deformity and wound complications.

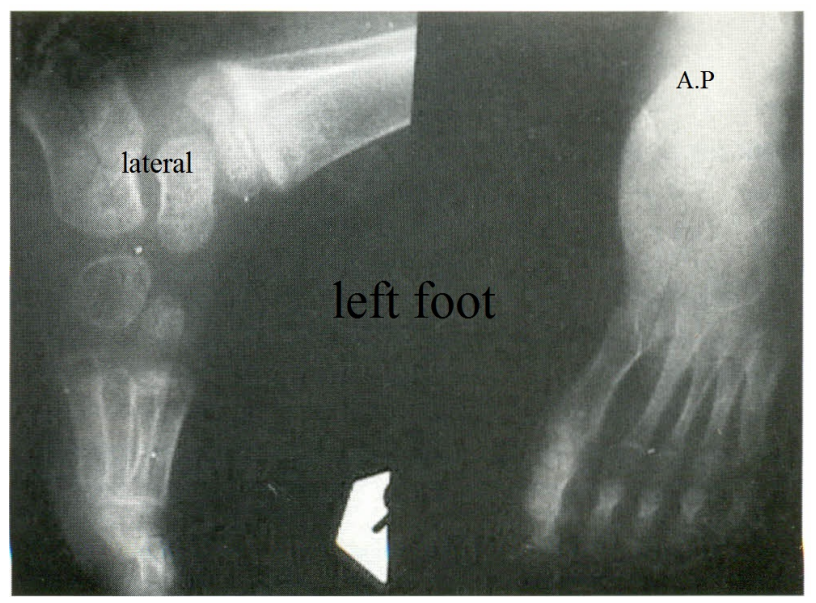

(a)
This problem is solved by the Alkhooly external fixator, so the advantages of this technique are:

\begin{tabular}{cl}
\hline a & $\begin{array}{l}\text { Permitting dressing of the wounds } \\
\text { b }\end{array}$ \\
Maintenance of the correction and gradual correction \\
Observation of the circulation and prevention of \\
neurovascular complications by gradual correction \\
when needed. \\
d & Good correction of healing inversion \\
\hline
\end{tabular}

In one of the published reports [29], it was observed that half of their cases of the series after completion of treatment had only a false correction of the deformity. The foot was broken at the talonavicular level, leaving the heel in inversion although the forefoot was plantigrade; this meant that plaster cast could not maintain the correction of inversion of the heel. By using the fixator, inversion of the heel can be corrected and maintained by changing the position of $\mathrm{K}$. wire passing through the calcaneus in the holes of proximal half ring.

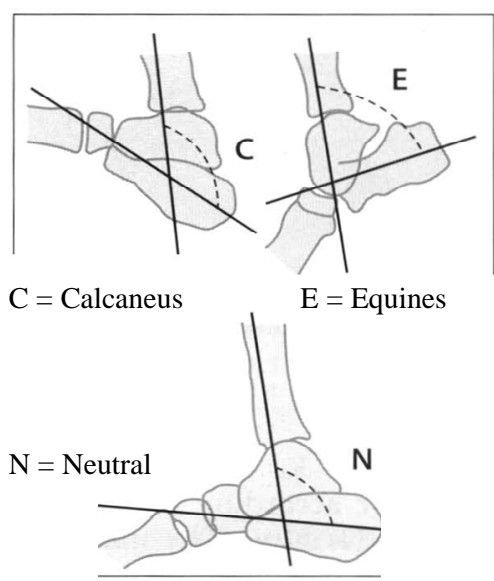

Figure 4. Diagram showing the tibio-calcaneal angle as traced. On the lateral $\mathrm{X}$-ray to measure the ankle equines.

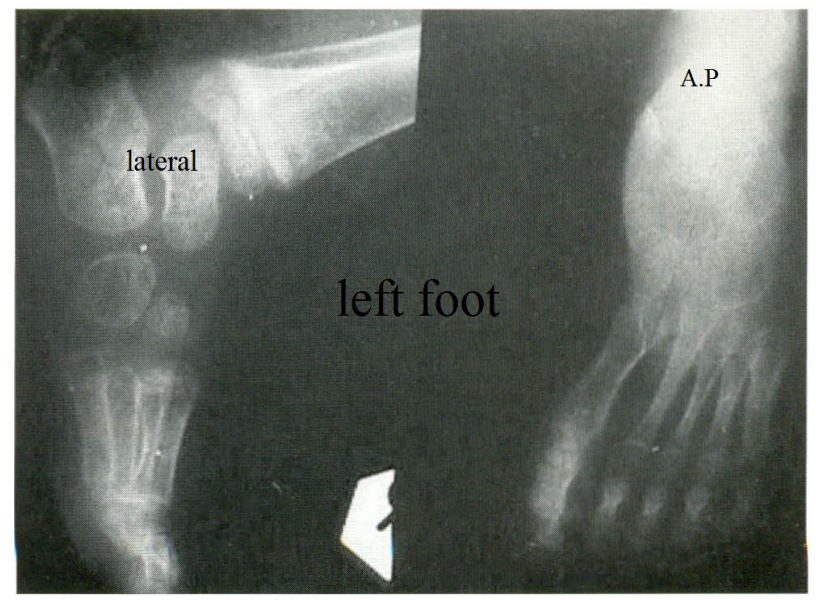

(b)

Figure 5. (a) Pre operative X-ray (left foot); (b) Post operative follow up X-ray (left foot). 


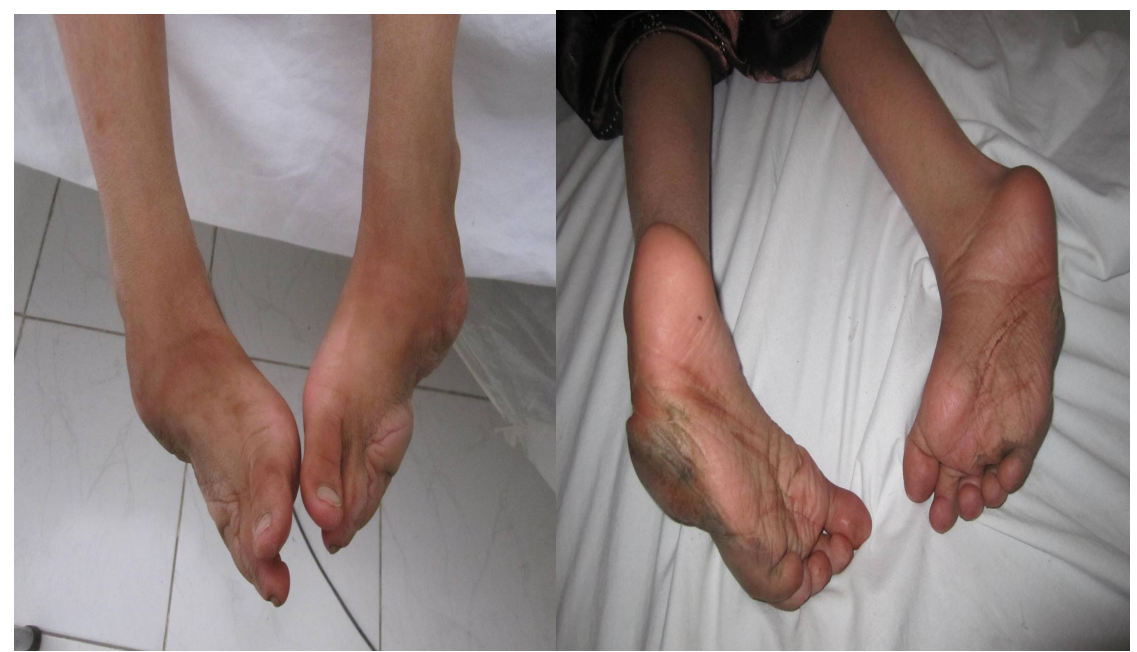

(a)

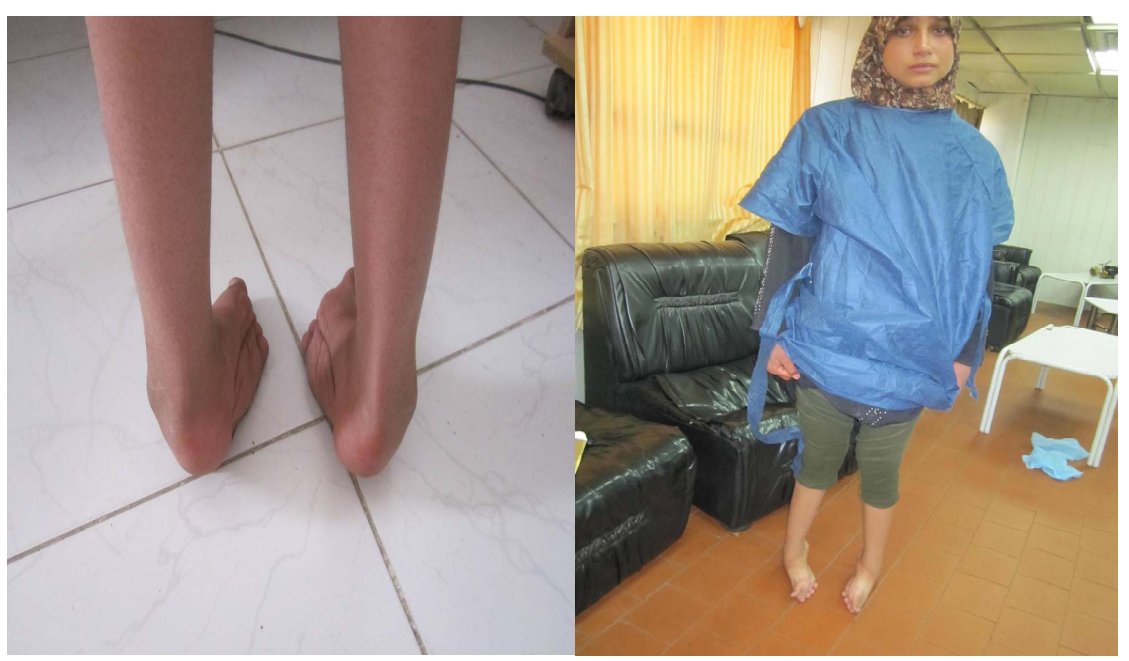

(b)

Figure 6. (a) Case of bil. Congenital talipes equino-varus (Pre-operative photos). (b) The same case while standing (Pre-operative photos).

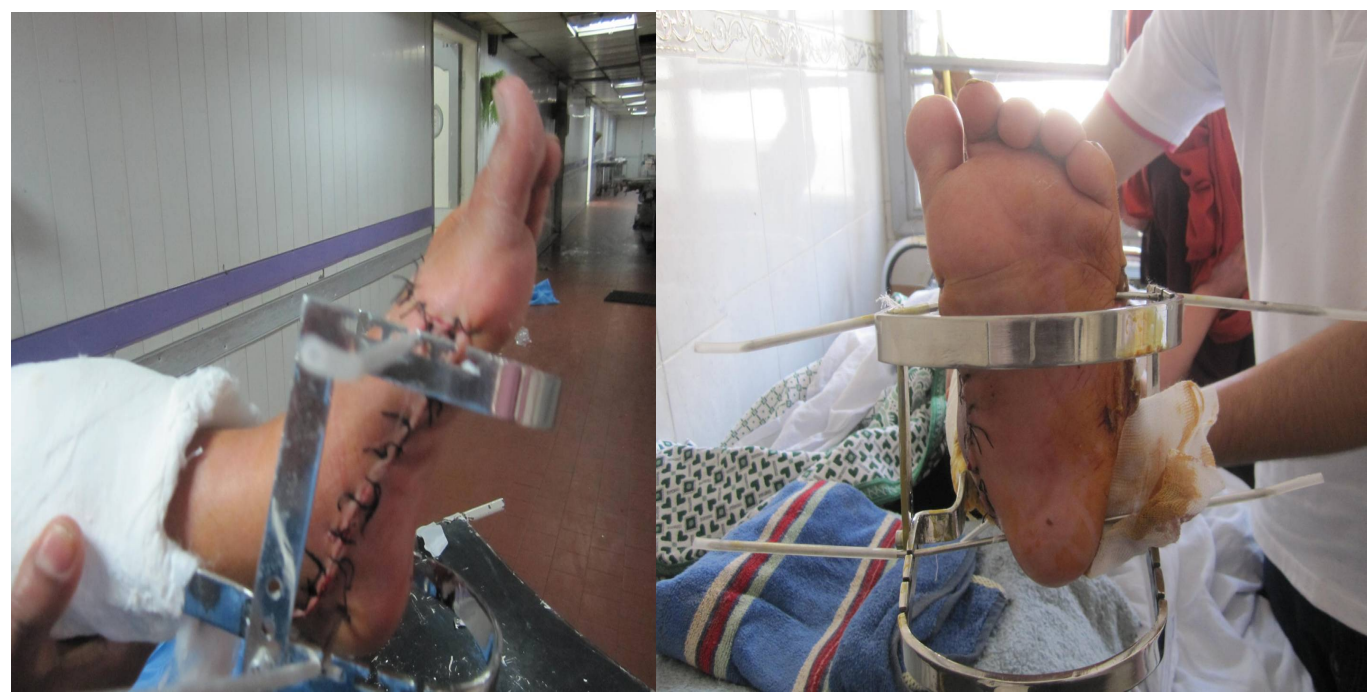

Figure 7. Post-operative photos in the fixator. 


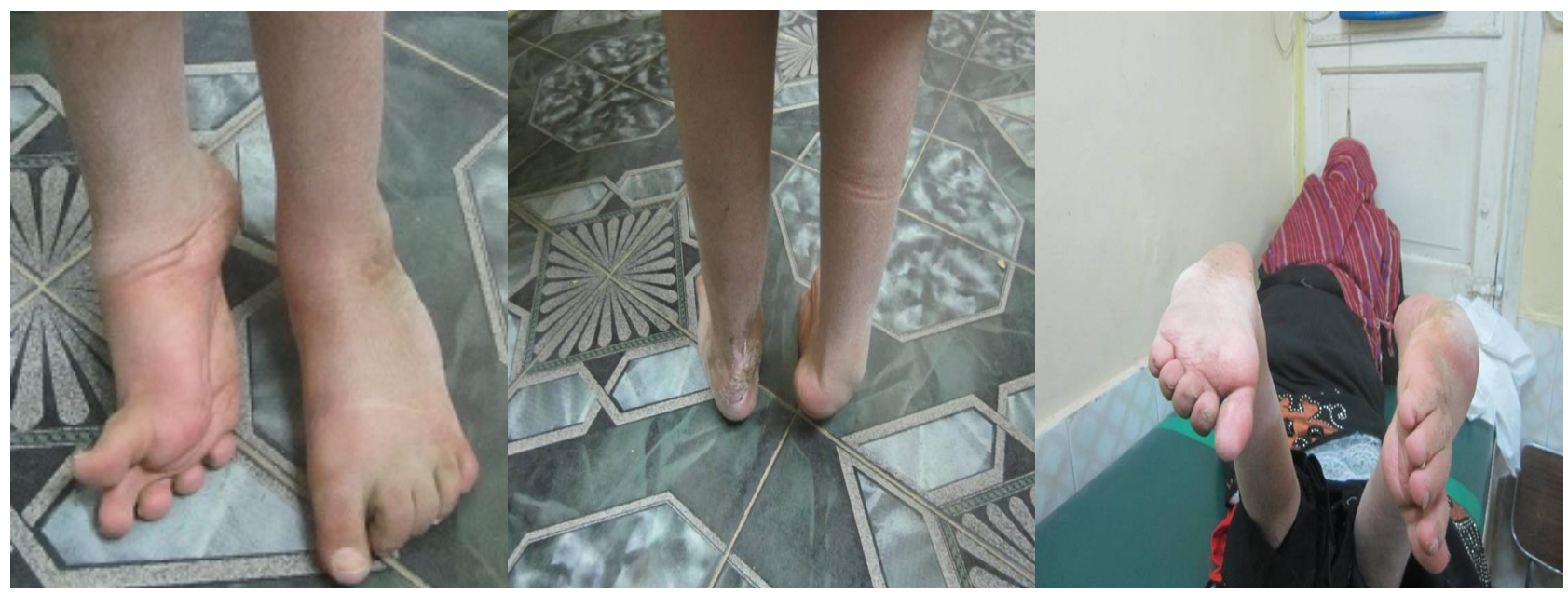

Figure 8. Post-operative follow up, left side operated and right side not operated yet.

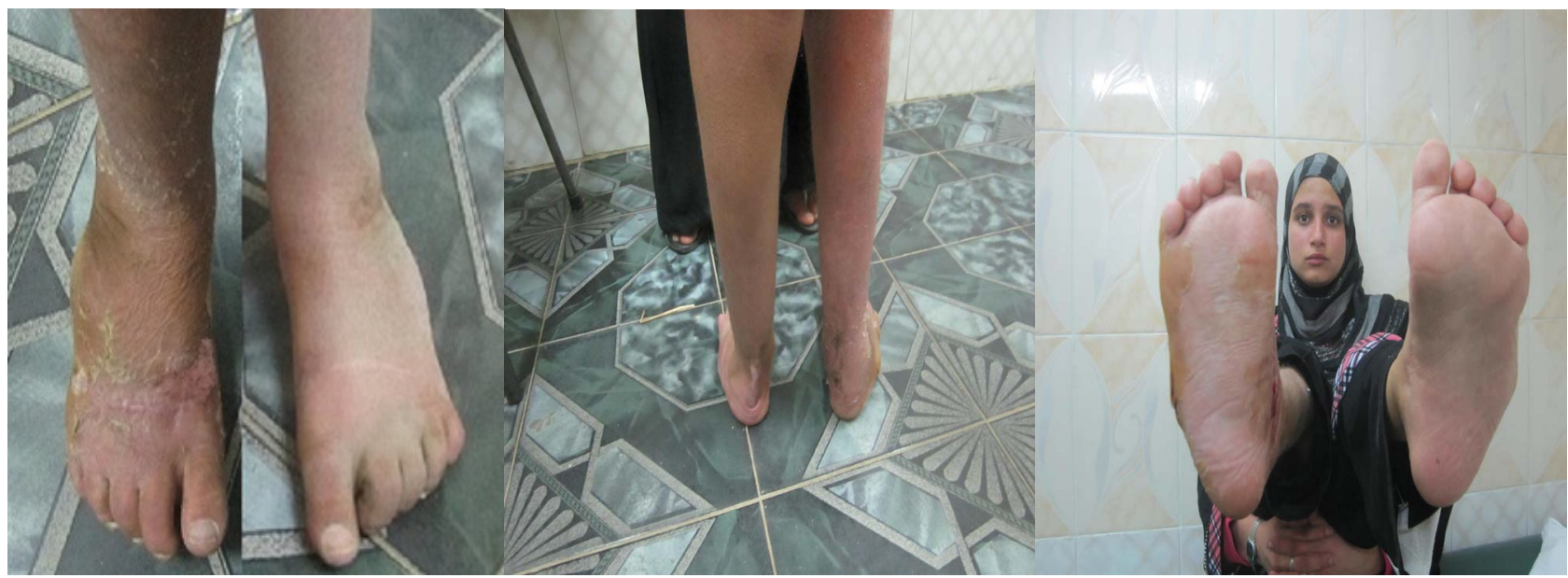

Figure 9. Both feet after correction.

Mittal [15] reported that even in a normal looking foot there was sometimes radiological under-correction of the talo-calcaneal index and/or calcaneo-metatarsal angle; however, substantial radiological improvement had occurred in every case whenever X-ray was taken. In addition, Wynne-Davies [29] in his review of patients after treatment of talipes equino-varus, radiological assessment revealed that only one fourth of the 121 feet examined showed normal alignment of the hind foot, another quarter showed some over-riding of talus and calcaneus or partial inversion, and one-half of the feet showed complete over-riding of the talus and calcaneus or full inversion of the heel, however, on clinical examination those feet were plantigrade. Most of our cases show radiological correction after two years of follow-up as shown in the X-ray. Similarly, Sherman and Westin [30] stated in 1981 that there was no standard method to measure equinus angulation of the calcaneus. So, clinical correction was, therefore, always relied upon when assessing the results.
Our results are encouraging for using this technique.

\section{REFERENCES}

[1] R. L. Mittal, “The Surgical Management of Resistant Clubfoot by Rotation Skin Flap and Extensive Soft Tissue Release,” International Orthopedics (SICOT), Vol. 11, No. 3, 1987, pp. 189-192. http://dx.doi.org/10.1007/BF00271446

[2] J. J. Gartland, "Posterior Tibial Transplant in the Surgical Treatment of Recurrent Club Foot," The Journal of Bone \& Joint Surgery, Vol. 46, No. 6, 1964, pp. 1217-1225.

[3] A. Fried, "Recurrent Congenital Clubfoot: The Role of m. tibialis Posterior in Etiology and Treatment,” The Journal of Bone \& Joint Surgery, Vol. 41, 1959, pp. 243-252.

[4] A. M. Wiley, "Club Foot. An Anatomical and Experimental Study of Muscle Growth 1," The Journal of Bone \& Joint Surgery, Vol. 41, No., 1959, pp. 821-835.

[5] G. J. Garcean, “Congenital Talipes Equinovarus,” Instructional Course Lectures, the American Academy of Orthopaedic Surgeons, CV Mosby Co., St. Louis, 1961, 
pp. 178-183.

[6] R. N. Irani and M. S. Sherman, "The Pathological Anatomy of Clubfoot,” The Journal of Bone \& Joint Surgery, Vol. 45, No. 1, 1963, pp. 45-52.

[7] G. W. Settle, “The Anatomy of Congenital Talipes Equinovarus: Sixteen Dissected Specimens," The Journal of Bone \& Joint Surgery, Vol. 45, No. 7, 1963, pp. 13411354.

[8] A. Berteslson, “Treatment of Congenital Club Foot," The Journal of Bone \& Joint Surgery, Vol. 39, 1957, pp. 539-599.

[9] M. Singer and A. T. Fripp, "Tibialis Anterior Transplant in Congenital Clubfoot," The Journal of Bone \& Joint Surgery, Vol. 40, 1958, pp. 252-255.

[10] T. R. Beatson and J. R. Pearson, "A Method of Assessing Correction in Club Foot," The Journal of Bone \& Joint Surgery, Vol. 48, 1966, pp. 40-50.

[11] C. G. Atfenborough, "Severe Congenital Talipes Equinovarus,” The Journal of Bone \& Joint Surgery, Vol. 48, No. 1, 1966, pp. 31-39.

[12] V. J. Turco, "Surgical Correction of the Resistant Clubfoot,” The Journal of Bone \& Joint Surgery, Vol. 53, No. 3, 1971, pp. 477-497.

[13] B. J. Main, R. J. Crider, M. Polk, G. C. Lioyd Reberts, M. Swann and B. A. Kamdar, "The Results of Early Operation in Talipes Equinovarus," The Journal of Bone \& Joint Surgery, Vol. 59, No. 3, 1977, pp. 337-341.

[14] J. G. Pous and A. Dimeglio, "Neonatal Surgery in Clubfoot," Orthopaedic Clinics of North America, Vol. 9, No. 1, 1978, pp. 233-240.

[15] A. H. Crawford, J. L. Marxen and D. L. Osterfeld, "The Cincinnati Incision: A Comprehensive Approach for Surgical Procedures of the Foot and Ankle in Childhood," The Journal of Bone \& Joint Surgery, Vol. 64, No 9, 1982, pp. 1355-1358.

[16] I. V. Ponseti and E. N. Smoley, "Congenital Clubfoot: The Results of Treatment," The Journal of Bone \& Joint Surgery, Vol. 45, No. 2, 1963, pp. 261-344.

[17] K. Tayton and P. Thompson, "Relapsed Clubfoot, Late Results of Delayed Operation," The Journal of Bone \& Joint Surgery, Vol. 61, No. 4, 1979, pp. 474-480.

[18] J. L. Lenoir, "Varus Deformity of the Heel," Othopaedic Review, Vol. 5, 1976, p. 35.
[19] T. Duckworth, "Hindfoot and Its Relations to Rotational Deformities of the Forefoot," Clinical Orthopaedics, Vol. 177, 1983, pp. 39-48.

[20] J. Bosch, "Operative oder Konservative Klumpfußbehandlung,” Zeitsch Orthopaedics, Vol. 83, 1953, pp. 824.

[21] D. W. McKay, "New Concept of and Approach to Club Foot Treatment Section 1. Principles and Morbid Anatomy,” Journal of Pediatric Orthopaedics, Vol. 23, 1982, pp. 47-56

[22] H. Bensahel, Z. Csukanyi, Y. Des Glrippes and P. Chaumien, "Surgery on Residual Club Foot, One Stage Medio-Posterior Release, a la Carte,” Journal of Pediatric Orthopaedics, Vol. 7, 1987, pp. 145-148.

[23] P. Siguda, G. Fritz and K. H. Ulbricht, "Neue Untersuchungsergebnisse der Klurnpfuflbehandlung," Therapiewo-che, Vol. 32, No., 1982, pp. 4610-4613.

[24] F. Grill and L. Franke, "The Ilizarov Distractor for the Correction of Re-Lapsed or Neglected Clubfoot," The Journal of Bone \& Joint Surgery, Vol. 69, No., 1987, pp.

[25] H. L. Henkel, "Die Behandlung des angeborenen Klumpfuf in Sauglings und Kindesalter. Beihefte zur Zeitschrift fiir Orthopadie vereinigt mit Aktuelle Orthopadie,” Enke Verlag, Stuttgart, 1974.

[26] V. J. Turco, "Resistant Congenital Clubfoot. One Postero-Medial Release with Internal Fixation. A Follow Up Report of a Fifteen Year Experience," The Journal of Bone \& Joint Surgery, Vol. 61, No., 1978, pp. 805-808.

[27] R. B. Smith, "Dysplasia and the Effect of Soft Tissue Release in Congenital Talipes Equinovarus," Clinical Orthopaedics, Vol. 174, No., 1983, pp. 303-309.

[28] G. P. Serosa and D. Stepro, "Results of Posteromedial Release for the Resistant Club Foot," Journal of Pediatric Orthopaedics, Vol. 6, No. 5, 1986, pp. 590-595. Http://dx.doi.org/10.1097/01241398-198609000-00012

[29] R. Wynne-Davies, "Talipes Equinovarus, a Review of 84 Cases after Completion of Treatment," The Journal of Bone \& Joint Surgery, Vol. 46, No. 3, 1964, pp. 464-476.

[30] F. C. Sherman and G. W. Westin, "Plantar Release in the Correction of Deformities of the Foot in Childhood," The Journal of Bone \& Joint Surgery, Vol. 63, No. 9, 1981, pp. 1382-1389. 